\title{
New Formulation of Clethodim/Adjuvant at Control of Grass Weeds for Soybean Crops
}

\author{
Alan Serafini Betto, Rafael Dysarz, Rafaela Cinelli \\ Federal Institute of Rio Grande do Sul-IFRS, Campus Sertão, Brazil \\ Rubens Antonio Polito, Tamara Heck \\ Federal University of Pelotas-UFPel, Brazil \\ Anderson Luis Nunes \\ Federal Institute of Rio Grande do Sul-IFRS, Campus Sertão, Brazil
}

Received: May 14, 2020 Accepted: July 15, $2020 \quad$ Published: July 20, 2020

doi:10.5296/jas.v8i4.17036

URL: https://doi.org/10.5296/jas.v8i4.17036

\begin{abstract}
The use of ACCase-inhibiting herbicides without the correct addition of an adjuvant is a major cause of inefficient poaceous weed control. As such, this study aimed to assess the efficiency of a new clethodim/adjuvant formulated mixture in postemergence weed control for soybean crops. Two field experiments were conducted in the 2015/16 and 2016/17 growing seasons. A randomized block design, consisting of ten treatments with four repetitions, was used. The treatments and doses were: clethodim $\left(108 \mathrm{~g}\right.$ a.i. ha $\left.{ }^{-1}\right)+$ Lanzar $^{\circledR}$ $(0.5 \%)$, clethodim $\left(108 \mathrm{~g}\right.$ a.i. $\left.\mathrm{ha}^{-1}\right)+\operatorname{Nimbus}{ }^{\circledR}(0.5 \%)$, clethodim/adjuvant formulation at doses of $\left(84 \mathrm{~g}\right.$ a.i. ha $\left.{ }^{-1}\right),\left(96 \mathrm{~g}\right.$ a.i. ha $\left.{ }^{-1}\right),\left(108 \mathrm{~g}\right.$ a.i. ha $\left.{ }^{-1}\right),\left(120 \mathrm{~g}\right.$ a.i. ha $\left.{ }^{-1}\right),\left(132 \mathrm{~g}\right.$ a.i. ha $\left.{ }^{-1}\right)$, and (144 $\mathrm{g}$ a.i. $\left.\mathrm{ha}^{-1}\right)$, and a control with and without weeding. The formulated clethodim/adjuvant mixture showed high control at 7 days after application (DAA) in the 2015/16 growing season. At 28 DAA, formulation doses of $108 \mathrm{~g}$ a.i. ha-1 and higher exhibited superior weed control and the highest crop yields. Therefore, the use of correct adjuvant or formulated mixture is essential to increase the efficiency of clethodim herbicide.
\end{abstract}

Keywords: Glicine max; ACCase; tank mixture; absorption; formulated mixture

\section{Introduction}

Weed control in no-till systems has become a challenge for farmers due to weed resistance to 
existing mechanisms of action (Loureiro et al., 2017). These plants compete aggressively with soybean crops and can cause seed yield losses of more than 50\% (Vidal \& Trezzi, 2006; Barroso et al., 2010). Management practices that can lead to the selection of resistant weed biotypes include weed control using herbicides and repeatedly applying the same mechanism of action over several growing seasons (Jugulam \& Gill, 2018).

Using mechanisms of action other than EPSP inhibition (glyphosate) is important to reduce the selection pressure of this herbicide on weeds. Among current herbicides, ACCase inhibitors are the best alternative to control poaceous weeds (Melo et al, 2012), which exhibit highly competitive potential with soybean crops (Barroso et al., 2010).

The occurrence of herbicide-resistant weeds in sufficient density to limit crop yields signals the need to change the management practice used (Mwendwa et al., 2018) and improving the effectiveness of herbicides. One way to enhance the performance of herbicides is the addition of corrected adjuvants on tank-mixture (Prado et al, 2016; Alves et al, 2019), although this are not active ingredients, they influence application efficiency (Maciel et al., 2014). The mineral oil, for instance, is known to increase the efficiency of ACCase-inhibiting herbicides (Costa et al., 2013), in this way, those herbicides should be always used in association with an adjuvant (Sharma \& Renjith, 2016). In a study that used clethodim to control Urochloa plantaginea after soybean emergence, adding oil to the spray solution increased control from 75 to $97 \%$ (Puríssimo, 2002). Similarly, in comparison with other adjuvants, the oil mineral presented the best efficiency in the Avena sativa control with haloxifop herbicide (Shánchez, et al, 2018).

Achieving maximum agronomic efficiency in the postemergent management of weed species under no-till systems requires not only studies on the best application times, but combining available herbicides with adjuvants (Travlos, Cheimona \& Bilalis, 2017; Prado et al, 2016)). Given that adjuvants enhance the effects of herbicides, the package inserts for all ACCase inhibitors recommend the addition of adjuvants. However, in some cases herbicides are sprayed without an adjuvant or, more frequently, in conjunction with a non-recommended adjuvant. According to the usage, the adjuvants can be divided in formulation adjuvants, when they are part of the formulation, or spray adjuvants, when they are added in the tank mix (Coalova, et al, 2014).

The apparent improvement in efficacy through the addition of adjuvants is linked to an increase in the rate of herbicide absorption (Akhter et al., 2017; Santo et al., 2017). There is not any research about the efficiency of the clethodim/adjuvant formulated mixture in weed control. As such, the aim of this study was to assess the efficiency of a new clethodim/adjuvant formulated mixture in poaceous weed control after soybean emergence and its impact on seed yield.

\section{Materials and Methods}

\subsection{Experiment Site}

Two field experiments were carried out in the experimental area on the Sertão Campus of the Federal Institute of Education, Science and Technology of Rio Grande do Sul (2802'33"S, 
$\left.52^{\circ} 16^{\prime} 03^{\prime \prime W}\right), 705$ meters above sea level, in the 2015/16 and 2016/17 growing seasons, using Distroferric Red Nitisol, whose chemical characteristics are reported in Table 1. The characteristics of the water that was used to spray is: $\mathrm{pH} 6.6$, temperature $22.5^{\circ} \mathrm{C}$ and turbidity 2.3 NTU. The regional climate is humid subtropical (Cfa), according to the Köppen classification system.

Table 1. Result of chemical analysis of the soil in the experimental area for $0-10 \mathrm{~cm}$ soil layer

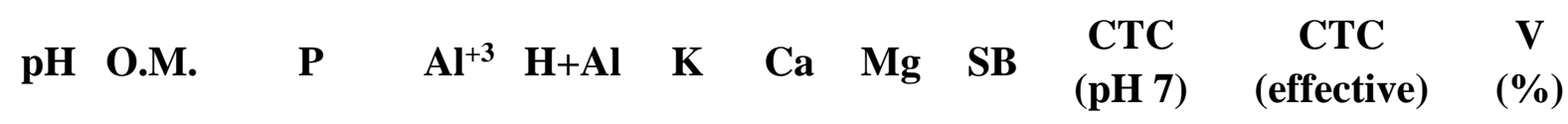

$\% \quad\left(\mathrm{mg} \cdot \mathrm{dm}^{-1}\right)$------------- $\left(\mathrm{cmol}_{\mathrm{c} .} \mathrm{dm}^{-3}\right)$

$\begin{array}{llllllllllll}5.1 & 2.9 & 19.8 & - & 4.31 & 0.28 & 6.98 & 2.53 & 9.79 & 14.11 & 9.8 & 69.43\end{array}$

$\mathrm{pH}$ : soil $\mathrm{pH}$; O.M.: organic matter; $\mathrm{Ca}$ : calcium; $\mathrm{Mg}$ : magnesium; $\mathrm{Al}$ : aluminum; $\mathrm{K}$ : potassium; P phosphorus; CTC: capacity of cations exchange; V\%: bases saturation

\subsection{Treatments and Experimental Design}

A randomized block design, consisting of ten treatments (Table 2) with four repetitions in both growing seasons, was used. The experimental units were $2 \mathrm{~m}$ wide (four rows) and $4 \mathrm{~m}$ long. The herbicides were applied after crop and weed emergence, when plants exhibited 3 to 4 tillers. Spraying was performed using a $\mathrm{CO}_{2}$ pressurized sprayer equipped with a boom containing four ceramic spray nozzles (Micron 11002/Air) spaced $0.50 \mathrm{~m}$ apart and capable of administering $150 \mathrm{~L} \mathrm{ha}^{-1}$ of spray solution.

Table 2. Treatments used and their respective common and commercial names, doses, concentration and manufacturer

\begin{tabular}{lllll}
\hline Common Name & $\begin{array}{l}\text { Commercial } \\
\text { Name }\end{array}$ & $\begin{array}{l}\text { Dose } \\
\text { g a.i ha }{ }^{-1}\end{array}$ & $\begin{array}{l}\text { Concentration/ } \\
\text { formulation }\end{array}$ & Adjuvant \\
\hline Control with Weeding & -- & -- & -- & -- \\
Weed-free Control & -- & -- & -- & -- \\
Clethodim & Select & 108 & $240 \mathrm{EC}$ & Lanzar ${ }^{\circledR}$ \\
Clethodim & Poquer & 108 & $240 \mathrm{EC}$ & Nimbus ${ }^{\circledR}$ \\
Clethodim/adjuvant & Select One Pack & 84 & $120 \mathrm{EC}$ & -- \\
Clethodim/adjuvant & Select One Pack & 96 & $120 \mathrm{EC}$ & --
\end{tabular}




$\begin{array}{llll}\text { Clethodim/adjuvant } & \text { Select One Pack } 108 & 120 \text { EC } \\ \text { Clethodim/adjuvant } & \text { Select One Pack } 120 & 120 \text { EC } \\ \text { Clethodim/adjuvant } & \text { Select One Pack } 132 & 120 \text { EC } & -- \\ \text { Clethodim/adjuvant } & \text { Select One Pack } 144 & 120 \text { EC } & --\end{array}$

\subsection{Experiment Details}

Both experiments were conducted in a no-till system with a wheat-soybean cropping sequence. Desiccation was not performed and the few dicotyledonous weeds that emerged in the experimental areas were removed by hand. Planting occurred on November 22, 2015 and December 11, 2016 using the Nidera 5959 IPRO cultivar, at a density of 350,000 seeds ha ${ }^{-1}$ and $45 \mathrm{~cm}$ between rows. The adjuvants were added in line with recommendations on the package insert, at $0.5 \%$ of the spray solution volume. The predominant weeds were identified as Alexandergrass (Urochloa plantaginea), Jamaican crabgrass (Digitaria horizontalis), Goosegrass (Eleusine indica) and common wheat (Triticum aestivum).

\subsection{Data Collect}

Weed control was assessed visually at 7, 14, 21 and 28 days after application (DAA) of the treatments, using a percentage scale from 0 to $100 \%$, where 0 indicates no symptoms and $100 \%$ the death of all plants. Weed dry weight was evaluated at 28 DAA by collecting weed shoots from a $0.25 \mathrm{~m}^{2}$ area per plot, which were then dried in an oven at $62^{\circ} \mathrm{C}$. Seed yield was calculated based on the weight of the manually harvested seeds (two central rows of the plots, disregarding $0.5 \mathrm{~m}$ at each end) and extrapolated to hectares, with moisture content subsequently standardized to $13 \%$. Climate data during the crop development stages were obtained from the Brazilian Agricultural Research Company (EMBRAPA).

\subsection{Statistical Analysis}

The variables were submitted to ANOVA using ASSISTAT software (Silva and Azevedo, 2002). The data were submitted to root square transformation plus one. The year was considered a random variable and the main effects of the herbicide treatment were tested for year-associated error based on treatment interaction. The data were grouped over the years when significant year-x-treatment interaction did not occur. The difference between the means was determined by Tukey's test at 5\% probability and graphs were generated using Sigmaplot software (version 11.0).

\section{Results and Discussion}

\subsection{Climatic Condition}

The climate in both growing seasons was characterized as El Niño, with above average rainfall for southern Brazil. In the 2015/16 season, January was marked by a period of drought with irregular rainfall at levels below historic records, whereas rainfall in 2016/17 
was normal and well-distributed over 10-day periods during soybean development (Figure 1).
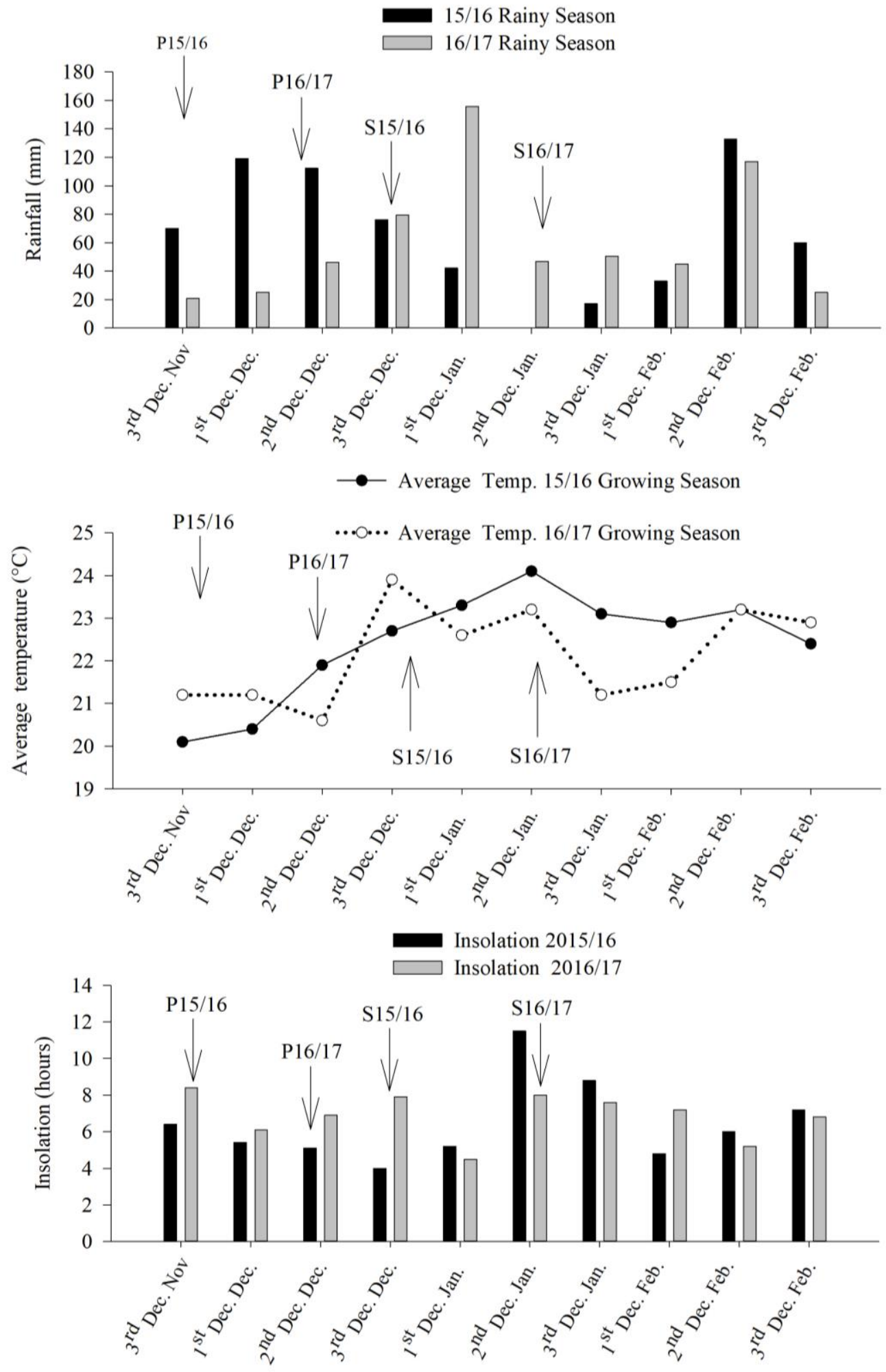

Figure 1. Rainfall, average temperature and insolation, over 10-day periods, in Sertão-RS in the 2015/16 and 2016/17 growing seasons

Abbreviations: P 15/16 = planting 2015/16 growing season; P 16/17 = planting 2016/17 
growing season; S15/16 = treatment spraying 2015/16 growing season; S16/17 = treatment spraying 2016/17 growing season.

\subsection{Weed Control}

Analysis of variance for toxicity caused by the herbicides at 7, 14, 21 and 28 DAA showed interaction between the herbicides and growing seasons. In the 2015/16 crop, the treatments with clethodim/adjuvant showed greater toxicity to weeds at 7 and 14 DAA, indicating faster control. Herbicide-related symptoms were slower to emerge in the 2016/17 season compared to $2015 / 16$, with significant control similar to the first year of the experiment only observed at 14 DAA for the highest formulated mixture doses, and at 21 and 28 DAA for all the herbicides (Figure 2), this difference is likely climate related. The effects of the herbicides intensified in 2015/16 due to a drought, with periods of higher insolation and temperatures, these climatic conditions heighten the efficacy of ACCase inhibitors (Cieslik, et al, 2013). The highest level of insolation improving metabolic activity, especially photosynthesis, which influences by increasing the translocation of the product within the plant; regarding to temperature, when the plants are exposed to lower temperature increase the leaf wax and decreased metabolism, resulting in lower absorption and translocation (Cieslik et al, 2013). The use of ACCase inhibitors under suboptimal conditions and doses has prompted weed mutations, making them resistant to these herbicides (Saini et al., 2015).

A comparison between the herbicides at 7 DAA in the 2015/16 growing season indicated control greater than $60 \%$ for all treatments except clethodim+Nimbus ${ }^{\circledR}$, this can be explained for the fact that each adjuvant act in different ways (Cunha et al, 2017). In the growing season 2016/17 no differences between herbicides at 7 DAA. At 14 and 21 DAA, clethodim/adjuvant doses greater than $96 \mathrm{~g}$ a.i. $\mathrm{ha}^{-1}$ showed superior control compared to the remaining treatments, and greater efficiency in the 2016/17 season (Figure 2). However, although weed growth stops immediately after ACCase inhibitor application, symptoms of the herbicide are not immediately apparent because of its slow translocation and action in the meristems (Maciel et al., 2014).

With respect to toxicity, at 28 DAA doses larger than $108 \mathrm{~g}$ a.i. $\mathrm{ha}^{-1}$ of the clethodim/adjuvant formulated mixture exhibited control greater than $90 \%$, a significant difference in relation to the other treatments (Figure 2). In Lolium multiflorum control, symptom evolution is related to the herbicide (clethodim) dose applied, that is, the higher the dose, the more rapidly symptoms progress (Vargas et al., 2006). There were no differences between herbicides in the 2016/17 crop (Figure 2). 


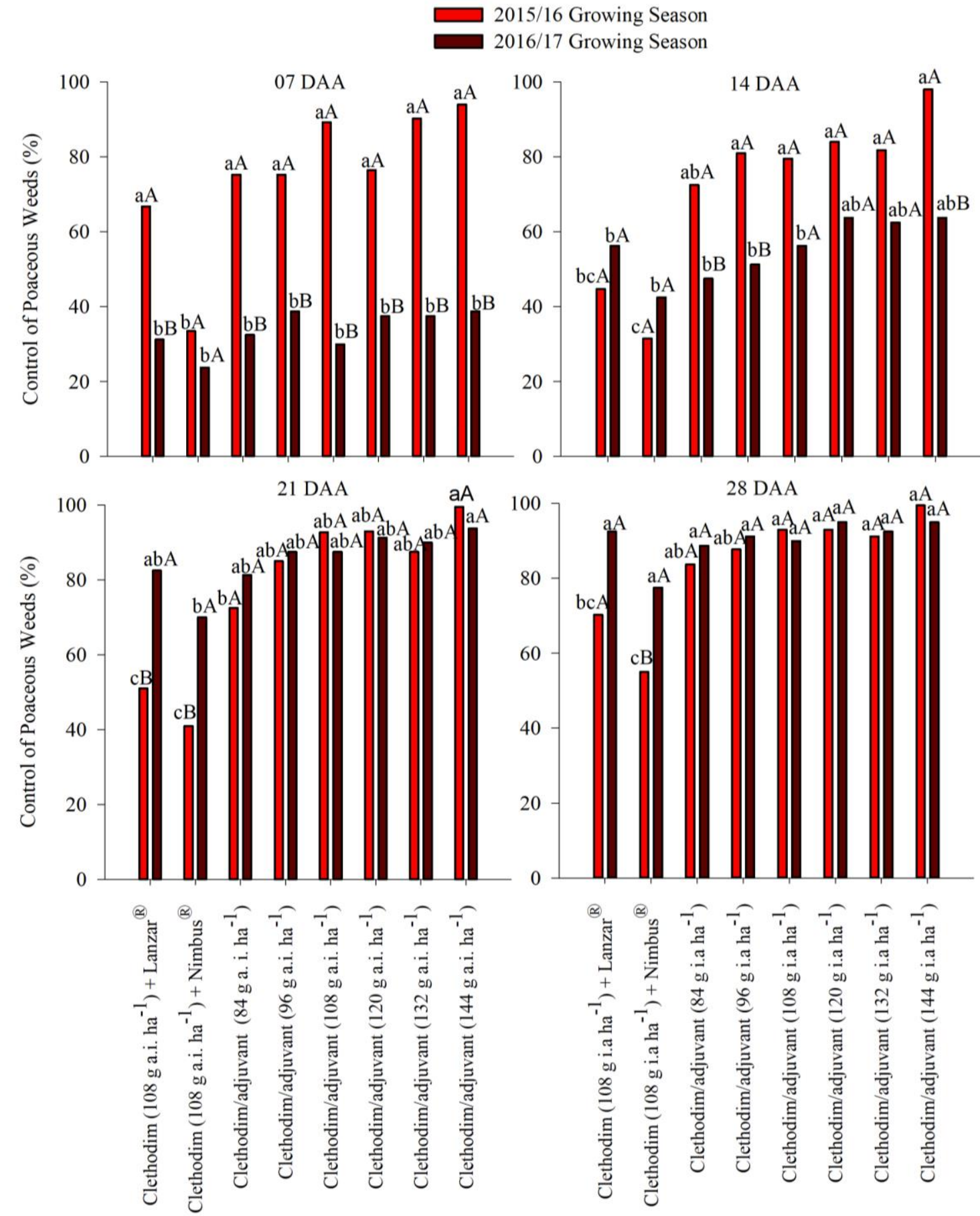

Figure 2. Control of Poaceous Weeds (\%) as a function of the herbicide treatments at 7, 14, 21 and 28 days after application (DAA)

Means followed by the same lower case letter do not differ within the same growing season according to Tukey's test at 5\%. Means followed by the same upper case letter do not differ in different years according to Tukey's test at 5\%.

\subsection{Number of Weeds and Dry Weight}

Differences were observed between the herbicides for the number of weeds variable. The 


\section{Macrothink

factor years and herbicide $\mathrm{x}$ year interaction showed no significant differences. The same was true for the variables weed dry weight and yield, therefore, the data on these variables are presented as an average for the two-year growing seasons. The smallest number of weeds was recorded for the clethodim/adjuvant treatment at doses of 120, 132 and $144 \mathrm{~g}$ a.i. ha ${ }^{-1}$, indicating better control than the herbicides that require an adjuvant in the spray solution (Figure 3). This demonstrates the importance of using the correct adjuvant with ACCase inhibitors, as is the case of the clethodim/adjuvant formulated mixture, which shows the correct combination of adjuvant type and dose. The formulated mixture also avoids mistakes on the tank mix, since there is not enough information about this (Gazzieiro, 2015), the farmers usually do not have the preparing to perform this technique. The clethodim/adjuvant herbicides at 120, $132 \mathrm{e} 144 \mathrm{~g}$ a.i. $\mathrm{ha}^{-1}$ exhibited fewer weeds at the end of the experiment in relation to the other treatments (Figure 3). These results indicate the importance of the adjuvant in improving the efficiency of ACCase inhibitors and, particularly, that adjuvants differ. The importance and efficiency of adjuvants is especially evident when they are used for weed control under unfavorable conditions (Maciel et al., 2014). The use of oils as adjuvants in spray solutions with systemic postemergent herbicides can increase weed absorption of the active ingredient, improving control (Mendonça, 2003).

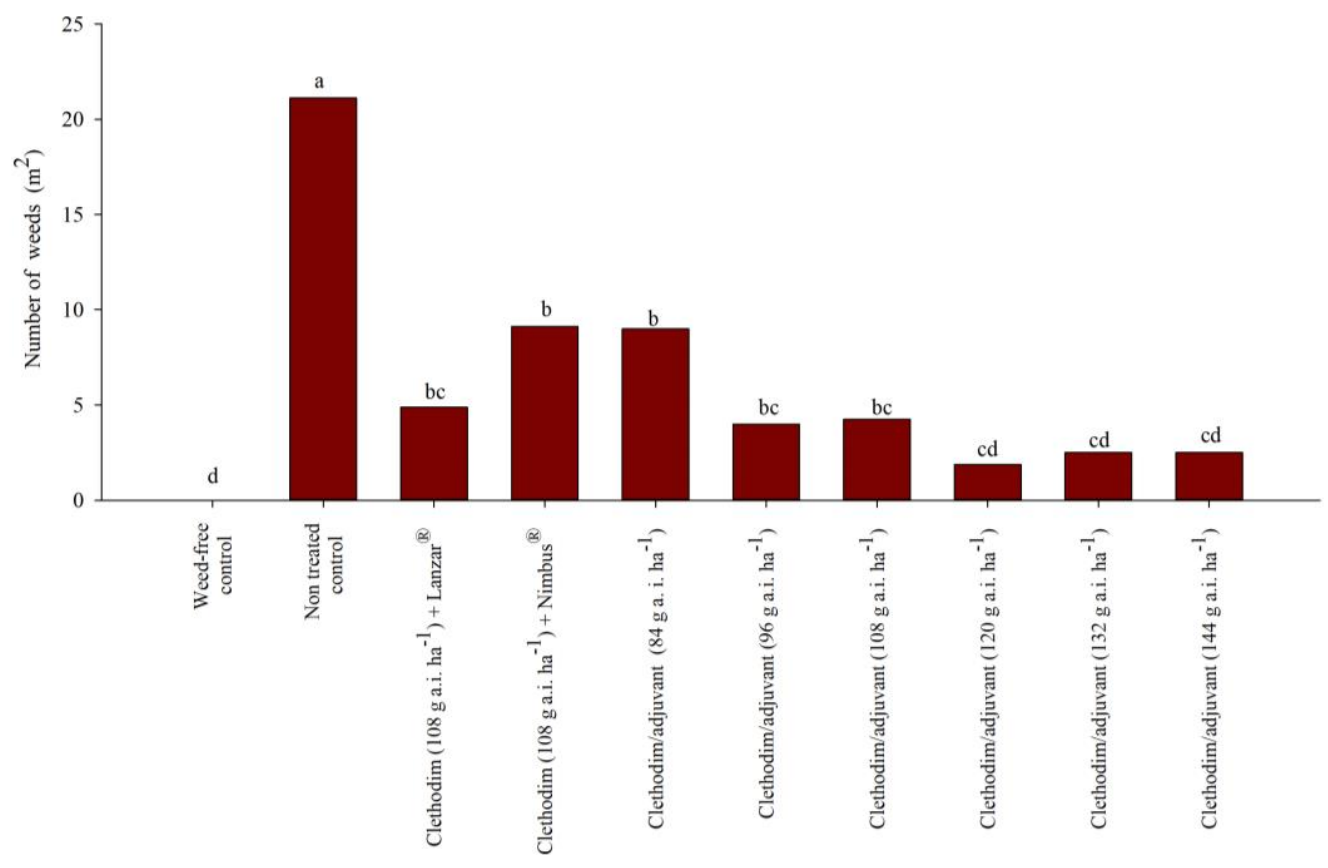

Figure 3. Number of weeds $\left(\mathrm{m}^{2}\right)$ as a function of herbicide treatments at the end of the experiment

Means followed by the same lower case letter do not differ within the same assessment period according to Tukey's test at 5\%.

Analysis of weed dry weight indicated low values in treatments with small final weed numbers, with the lowest dry weight recorded for the clethodim/adjuvant herbicide at doses 


\section{Macrothink

over $96 \mathrm{~g}$ a.i. ha ${ }^{-1}$ (Figure 4). Analysis of clethodim toxicity in the control of Cynodon dactylon revealed symptoms for all the formulations/concentrations used (120 and $\left.240 \mathrm{~g} \mathrm{~L}^{-1}\right)$. However, there was a greater decline in weed dry weight for the $120 \mathrm{~g} \mathrm{~L}^{-1}$ formulation at 140 $\mathrm{g}$ a.i ha- 1 than the $240 \mathrm{~g} \mathrm{~L}^{-1}$ formulation at $140 \mathrm{~g}$ a.i. ha ${ }^{-1}$ (Nandula et al., 2007).

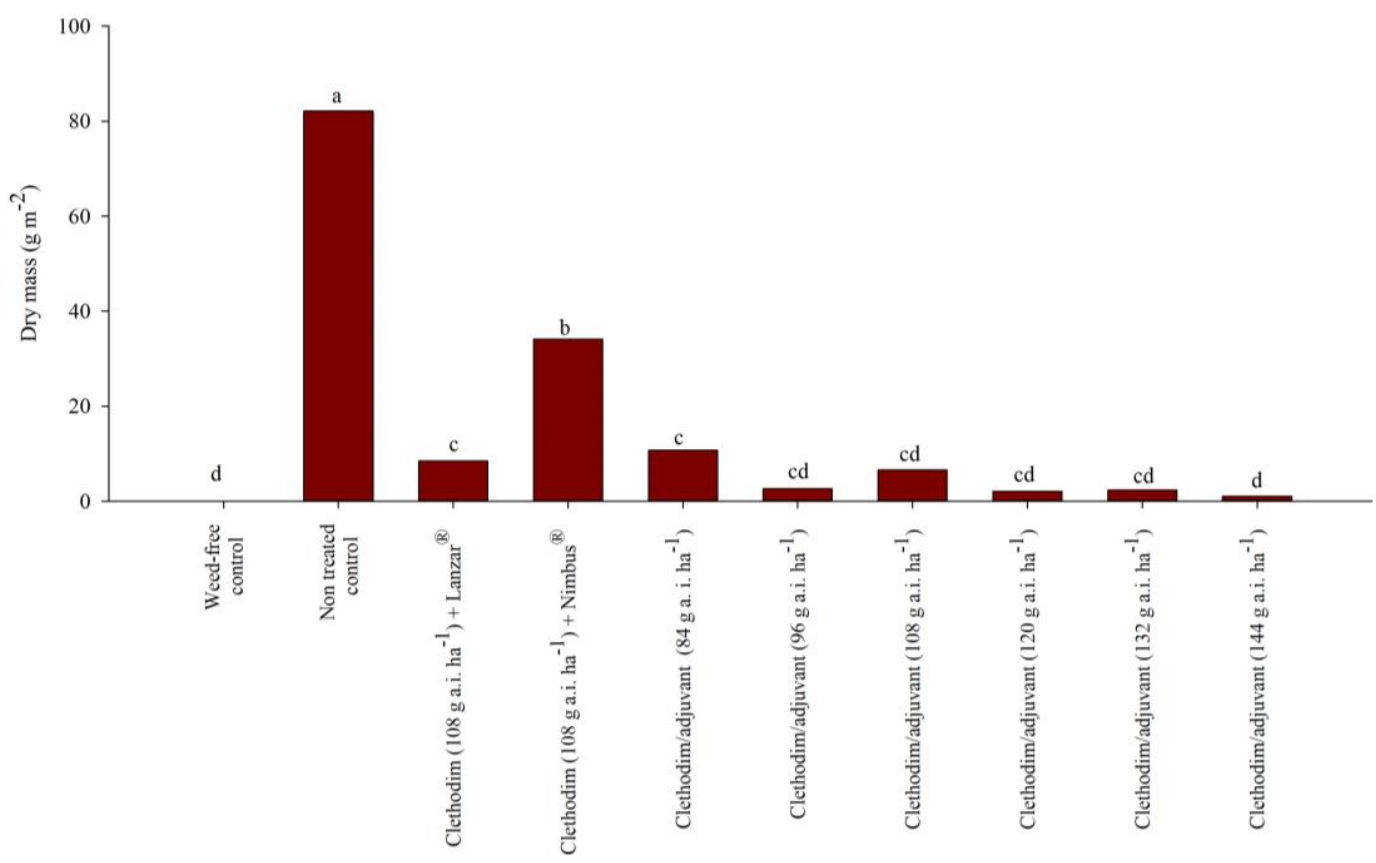

Figure 4. Weed dry weight $\left(\mathrm{g} . \mathrm{m}^{-2}\right)$ as a function of herbicide treatments at the end of the experiment

Means followed by the same lower case letter do not differ within the same assessment period according to Tukey's test at 5\%.

\subsection{Soybean Yield}

The yield results demonstrated that poaceous weed infestation of the soybean crop prompted a $2064 \mathrm{~kg} \mathrm{ha}^{-1}$ decline in seeds compared to the weed-free control (Figure 5). The weed interference in soybean during all the crop cycle reduces yield 73 to $94 \%$ in different sowing times (Zandona, et al, 2018). Considering a 5\% tolerable yield decline, the soybean crop was negatively affected by weed infestation starting at 25 DAE (PAI) (Benedetti et al., 2009). The inefficient poaceous weed control provided by the control without herbicide and resulting increase in weed interference with the soybean crop caused a significant decrease in seed yield (600 to $1400 \mathrm{~kg} \mathrm{ha}^{-1}$ ) (Puríssimo, 2002).

The clethodim+Nimbus ${ }^{\circledR}$ treatment was the only herbicide whose yield differed from that of the weed-free control (Figure 5). Emphasizing one more time the importance of using the correct adjuvant for each herbicide. Doses over $96 \mathrm{~g}$ a.i. ha ${ }^{-1}$ of the clethodim/adjuvant formulated mixture exhibited good control and an increase of $1749.61 \mathrm{~kg} \mathrm{ha}^{-1}$ in seed yield in relation to the weed-free control (Figure 5). Competition of weeds with crops can generate 
irreversible losses, with no recovery of development or yield, even after the elimination of it (Agostinetto et al, 2014). Moreover, increase in the period when the crop remains with weed interference, greater the damage (Zandona et al, 2018).

This gain is related to the faster action of the clethodim/adjuvant herbicide in relation to the other formulations, thereby reducing weed interference in this economically important crop. The absorption and translocation of the clethodim herbicide with carbon 14 (14C) showed that absorption of the $120 \mathrm{~g} \mathrm{~L}^{-1}$ formulation 72 hours after application was $70 \%$ higher than that of the $240 \mathrm{~g} \mathrm{~L}^{-1}$ formulation (33\%). Thus, the lethal dose of clethodim was more frequently translocated in plants treated with the $120 \mathrm{~g} \mathrm{~L}^{-1}$ formulation compared to those that received the $240 \mathrm{~g} \mathrm{~L}^{-1}$ formulation (Nandula et al., 2007).

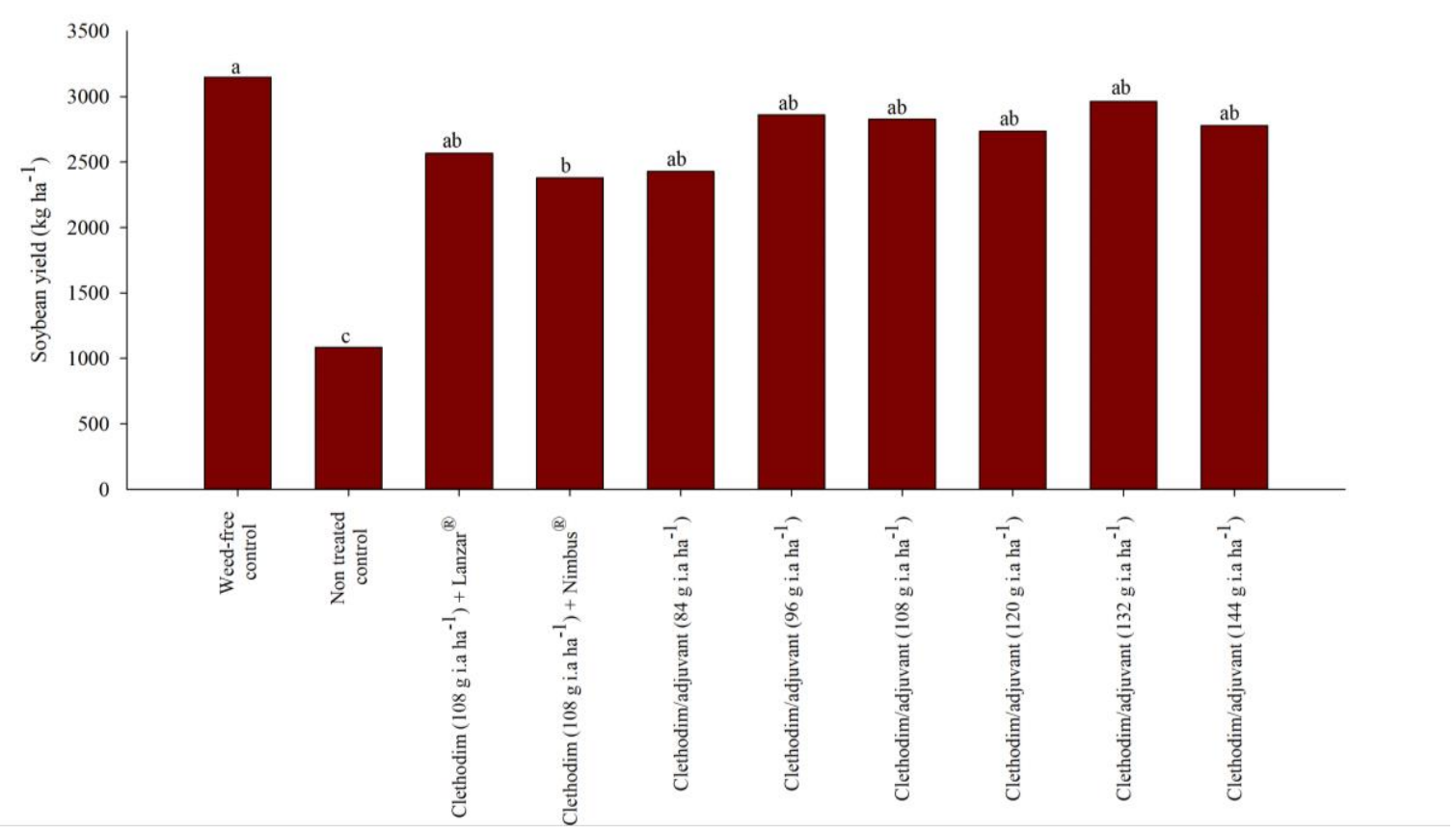

Figure 5. Soybean seed yield $\left(\mathrm{ha}^{-1}\right)$ as a function of herbicide treatments at the end of the experiment

Means followed by the same lower case letter do not differ within the same assessment period according to Tukey's test at 5\%.

\section{Conclusion}

The formulated mixture was efficient at controlling poaceous weeds, demonstrating superior control compared to the other clethodim formulations whose package inserts recommend the addition of adjuvants. Clethodim/adjuvant doses over $108 \mathrm{~g}$ a.i. ha ${ }^{-1}$ showed greater control and a smaller final number of weeds with lower dry weight values. There was an increase in soybean yield at clethodim/adjuvant dose of $96 \mathrm{~g}$ a.i. $\mathrm{ha}^{-1}$ or higher indicating that the formulated mixture acts more rapidly on weeds, reducing their interference with soybean crops.

In face of what was found, stands out the importance of use the right adjuvant with clethodim. 
Moreover, recommend to use the formulated mixture, clethodim/adjuvant, since it showed superior efficacy when compared to the tank mix adjuvant, besides that the formulated mixture has more security for avoiding possible mistakes, that can compromise the herbicide efficiency, when the adjuvant is add in the spray tank along with the herbicide.

Further research is suggested using the formulated mixture in association with other herbicides to determine the effect of these mixtures.

\section{References}

Agostinetto, D., Fontana, L. C., Vargas, L., Perboni, L. T., Polidoro, E., \& Silva, B. M. (2014). Competition periods of crabgrass with rice and soybean crops. Planta Daninha, 32(1), 31-38. https://doi.org/10.1590/S0100-83582014000100004

Akhter, M. J., Abbas, R. N., Waqas, M. A., Noor, M. A., Arshad, M. A., Mahboob, W., ... Gull, U. (2017). Adjuvant improves the efficacy of herbicide for weed management in maize sown under altered sowing methods. Journal of Experimental Biology and Agricultural Sciences, 5 (1), 22-30. https://doi.org/10.18006/2017.5(1).022.030

Alves, T. C., Assunção, H. H. T., Alves, G. S., Silva, S. M., \& Cunha, J. P. A. R. (2019). Tank mixture of pesticides and foliar fertilizers for Triozoida limbata control in guava trees (Psidium guajava L.). Revista Ceres, 66(4), 297-306. https://doi.org/10.1590/0034-737x201966040008

Barroso, A. L. L., Dan, H. A., Procópio, S. O., Toledo, R. E. B., Sandaniel, C. R., Braz, G. B. P. E., \& Cruvinel, K. L. (2010). Eficácia de herbicidas inibidores da ACCase no controle de gramíneas em lavouras de soja. Planta Daninha, 28(1), 149-157. https://doi.org/10.1590/S0100-83582010000100018

Benedetti, J. G. R., Pereira, L., Alves, P. L. C. A., \& Yamauti, M. S. (2009). Período anterior a interferência de plantas daninhas em soja transgênica. Scientia Agraria, 10(4), 289-295. https://doi.org/10.5380/rsa.v10i4.14801

Cieslik, L. F., Vidal. R. A., \& Trezzi, M. M. (2013). Fatores ambientais que afetam a eficácia de herbicidas inibidores da ACCase: revisão. Planta Daninha, 31(2), 483-489. https://doi.org/10.1590/S0100-83582013000200026

Coalova, I., Molina, M. C. R., \& Chaufan, G. (2014). Influence of the spray adjuvant on the toxicity effects of a glyphosate formulation. Toxicology in Vitro, 28, 1306-1311. https://doi.org/10.1016/j.tiv.2014.06.014

Costa, N. V., Pavan, G. C., Dourado, R. F., Costa, A. C. P. R., \& Vasconcelos, E. S. (2013). Seletividade de herbicidas aplicados com óleo mineral na cultura da mandioca 'Cascuda'. Revista Brasileira de Herbicidas, 12(3), 251-259. https://doi.org/10.7824/rbh.v12i3.204

Cunha, J. P. A. R., Guilherme, S. A., \& Marques, R. S. (2017). Tensão superficial, potencial hidrogeniônico e condutividade elétrica de caldas de produtos fitossanitários e adjuvantes. Revista Ciência Agronômica, 48(2), 261-270. http://dx.doi.org/ 10.5935/1806-6690.20170030 


\section{MInstitute ${ }^{\text {Macrothink }}$}

Gazziero, D. L. P. (2015). Misturas de agrotóxicos em tanque nas propriedades agrícolas do Brasil. Planta Daninha, 33(1), 83-92. https://doi.org/10.1590/S0100-83582015000100010

Jugulam, M., \& Gill, B. S. (2018). Molecular cytogenetics to characterize mechanisms of gene duplication in pesticide resistance. Pest Management Science, 74(1), 22-29. https://doi.org/10.1002/ps.4665

Loureiro, I., Escorial, C., Plaza, E. H., Andújar, J. L. G., \& Chueca, M. C. (2017). Current status in herbicide resistance in Lolium rigidum in winter cereal fields in Spain: Evolution of resistance 12 years after. Crop Protection, 102(1), 10-18. https://doi.org/10.1016/j.cropro.2017.08.001

Maciel, C. D. G., Lustosa, S. B. C., Silva, A. A. P., Karpinski, R. A. K, Souza, J. I., \& Helvig, E. O. (2014). Controle de milho voluntário $R^{\circledR}{ }^{\circledR}$ com a mistura em tanque de glyphosate + quizalofop-p-tefuril com adjuvantes multifuncionais ou óleos. Revista Brasileira de Herbicidas, 13(3), 252-257. https://doi.org/10.7824/rbh.v13i3.402

Melo, M. S. C., Rosa, L. E., Brunharo, C. A. C. G., Nicolai, M., \& Christoffoleti, P. J. (2012). Alternativas para o controle químico de capim-amargoso (Digitaria insularis) resistente ao glyphosate. Revista Brasileira de Herbicidas, 11(2), 195-203. https://doi.org/10.7824/rbh.v11i2.145

Mendonça, C. G. (2003). Efeito de óleos minerais e vegetais nas propriedades físico-químicas das caldas de pulverização e suas interações com superfícies foliares. Tese (Doutorado em Agronomia) - Curso de Pós-graduação em Agronomia, Faculdade de Ciências Agronômicas da UNESP, Botucatu. [Online] Available: https://repositorio.unesp.br/handle/11449/105439 (June 10, 2017).

Mwendwa, J. M., Brown, W. P., Wu, H., Weston, P. A., Weidenhamer, J. D., Kuinn, J. C., \& Weston, L. A. (2018). The weed suppressive ability of selected Australian grain crops, case studies from the Riverina region in New South Wales. Crop Protection, 103(1), 9-19. https://doi.org/10.1016/j.cropro.2017.09.003

Nandula,V. K., Poston, D. H., Reddy, K. N., \& Koger, S. H. (2007). Formulation and adjuvant effects on uptake and translocation of clethodim in bermudagrass (Cynodon dactylon). Weed Science, 55(1), 6-11. https://doi.org/10.1614/WS-06-024.1

Prado, E. P., Raetano, C. G., Dal Pogetto, M. H. F. A., Chechetto, R. G., Ferreira Filho, P. J., Magalhães, A. C., \& Miasaki, C. T. (2016). Effects of agricultural spray adjuvants in surface tension reduction and spray retention on Eucalyptus leaves. African Journal of Agricultural Research, 11(40), 3959- 3965. https://doi.org/ 10.5897/AJAR2016.11349

Puríssimo, C. (2002). Adjuvante em Soja. [Online] Available: https://www.grupocultivar.com.br/ativemanager/uploads/arquivos/artigos/gc40_adjuvante.pdf (June 10, 2017).

Saini, R. K., Kleemann, S. G. L., Preston, C., \& Gill, G. S. (2015). Alternative herbicides for the management of clethodim-resistant rigid Ryegrass (Lolium rigidum) in Faba Bean (Vicia 
faba L.) in Southern Australia. Weed Technology, 29(3), 578-586. https://doi.org/10.1614/WT-D-14-00143.1

Sanchez, P., Lutz, A. L., Magliano, M. F., Menapace, P., \& Scotta, R. R. (2018). Eficácia de haloxifop-R-metil com distintos coadyuvantes. Revista FAVE- Ciências Agrarias, 17(2), 63-69. https://doi.org/10.14409/fa.v18i2.7968

Santo, T. L. D. E., Mendonça, C. G., Graichen, F. A. S., Raetano, C. G., \& Teodoro, P. E. (2017). Control of Conyza bonariensis with glyphosate associated to adjuvants applied with different spray nozzles. Bioscience Journal, 33(20), 297-305. https://doi.org/10.14393/BJ-v33n2-33818

Sharma, R., \& Renjith, P. S. (2016). Sequential and tank-mix application of herbicides for weed management ensuring higher productivity of soybean (Glycine max). Indian Journal of Agricultural Sciences, 86(2), 197-201.

Silva, F. A. S., \& Azevedo, C. A. V. (2002). Versão do programa computacional Assistat para o sistema operacional Windows. Revista Brasileira de Produtos Agroindustriais, 4(1), 71-78. https://doi.org/10.15871/1517-8595/rbpa.v4n1p71-78

Travlos, I., Cheimona, N., \& Bilalis, D. (2017). Glyphosate Efficacy of different salt formulations and adjuvant additives on various weeds. Agronomy-Basel, 7(3), 1-9. https://doi.org/10.3390/agronomy7030060

Vargas, L., Roman, E. S., Rizzardi, M. A., \& Toledo, R. E. B. (2006). Manejo de azevém resistente ao glyphosate em pomares de maçã com herbicida Select (clethodim). Revista Brasileira de Herbicidas, 5(1), 27-31. https://doi.org/10.7824/rbh.v5i1.42

Vidal, R. A., \& Trezzi, M. M. (2006). Cresce a resistência das plantas. Visão agrícola, 5(2), 112-114. [Online] Available:

https://www.esalq.usp.br/visaoagricola/sites/default/files/va05-fitossanidade09.pdf (June 2, 2017).

Zandona, R. R., Agostinetto, D., Silva, B. M., Ruchek, Q., \& Fraga, D. S. (2018). Interference periods in soybean crop as affected by emergence times of weeds. Planta Daninha, 36, 1-11. https://doi.org/10.1590/s0100-83582018360100045

\section{Copyright Disclaimer}

Copyright for this article is retained by the author(s), with first publication rights granted to the journal.

This is an open-access article distributed under the terms and conditions of the Creative Commons Attribution license (http://creativecommons.org/licenses/by/4.0/). 